\title{
Replacement by a lacZ reporter gene assigns mouse connexin36, 45 and 43 to distinct cell types in pancreatic islets
}

\author{
Martin Theis, ${ }^{\mathrm{a}, 1}$ Christophe Mas, ${ }^{\mathrm{b}}$ Britta Döring, ${ }^{\mathrm{a}}$ Joachim Degen, ${ }^{\mathrm{a}}$ Christopher Brink,,${ }^{\mathrm{c}, 2}$ \\ Dorothée Caille, ${ }^{\mathrm{b}}$ Anne Charollais, ${ }^{\mathrm{b}}$ Olaf Krüger, ${ }^{\mathrm{a}}$ Achim Plum, ${ }^{\mathrm{a}, 3}$ Virginie Nepote, ${ }^{\mathrm{b}}$ \\ Pedro Herrera, ${ }^{\mathrm{b}}$ Paolo Meda, ${ }^{\mathrm{b}}$ and Klaus Willecke ${ }^{\mathrm{a}, *}$ \\ anstitut für Genetik, Abteilung Molekulargenetik, Universität Bonn, D-53117 Bonn, Germany \\ ${ }^{\mathrm{b}}$ Department of Morphology, University of Geneva, C.M.U., 1211 Geneva 4, Switzerland \\ ${ }^{\mathrm{c}}$ Max Planck Institute for Biophysical Chemistry, Am Fassberg 11, D-37077 Goettingen, Germany
}

Received 25 February 2003, revised version received 24 September 2003

\begin{abstract}
Transcripts of three connexin isoforms ( $\mathrm{Cx} 36, \mathrm{Cx} 43$ and $\mathrm{Cx} 45)$ have been reported in rodent pancreatic islets, but the precise distribution of the cognate proteins is still unknown. We determined expression of Cx36 in a cell-autonomous manner using mice with a targeted replacement of the $\mathrm{Cx} 36$ coding region by a lacZ reporter gene. For cell-autonomous monitoring of $\mathrm{Cx} 43$ expression, we used the Cre/loxP system: Mice carrying the $\mathrm{Cx} 43$ coding region flanked by loxP sites (floxed) also carried an embedded lacZ gene that is activated after Cremediated recombination in cells with transcriptional activity of the $C x 43$ gene. Deletion of the $C x 43$ coding region in $\beta$-cells did not result in the activation of the embedded lacZ reporter gene. Instead, $C x 43$ expression was found in endothelial cells of the islets of Langerhans in mice with endothelium-specific deletion. Ubiquitous deletion of $\mathrm{Cx} 43$ led to a similar endothelial lacZ expression, but again, activity of the reporter gene was not detected in $\beta$-cells. Mice with targeted replacement of the $\mathrm{Cx} 45$ coding region by lacZ showed a vascular expression similar to $\mathrm{Cx} 43$. The data show that native insulin-producing cells express a connexin isoform (Cx36) which differs from those (Cx43 and Cx45) expressed by vascular islet cells.

(C) 2003 Elsevier Inc. All rights reserved.
\end{abstract}

Keywords: Pancreas; Insulin secretion; $\beta$-cells; Vasculature; Connexins; Conditional gene replacement; Reporter gene; Cre; loxP

\section{Introduction}

Gap junction channels are formed by docking of two hemichannels, each contributed by one of two adjacent cells that allow for the intercellular diffusion (coupling) of molecules up to $1 \mathrm{kDa}[1]$. Hemichannels are hexamers of connexin proteins, which are encoded by a family of at least

* Corresponding author. Institut für Genetik, Abteilung Molekulargenetik, Universität Bonn, Römerstraße 164, D-53117 Bonn, Germany. Fax: +49-228-734263.

E-mail address: genetik@uni-bonn.de (K. Willecke).

${ }^{1}$ Present address: Center for Neurobiology and Behavior, Howard Hughes Medical Institute, Columbia University, New York, NY 10032, USA.

2 Present address: Division of Cell Biology, Biozentrum, University of Basel, Klingelbergstrasse 70, CH-4056 Basel, Switzerland.

${ }^{3}$ Present address: INGENIUM, Fraunhoferstr. 13, 82152 Martinsried, Germany.
19 genes in the mouse and 20 genes in the human genome [2]. Homotypic channels are formed by identical connexins, whereas heterotypic channels are formed by different hemichannels which, in turn, can be composed of either a single type of connexin (homomeric) or different connexins (heteromeric) [1]. Thus, depending on the connexin expression pattern, a variety of intercellular channels can be found that show distinct biophysical characteristics $[3,4]$. In particular, when connexin contribution differs between apposed cell types, different ionic selectivities of connexins might generate rectifying gap junctions [5] and selected signals may be preferentially exchanged between the coupled cells [6]. Eventually, gap junction channels can connect both similar and different cell types, depending on their connexin composition $[7,8]$. Therefore, understanding of gap junction functions in native tissues comprising multiple cell types requires each connexin isoform to be precisely allocated to specific cells. 
Within the pancreas, islets represent well-defined endocrine subunits made up of several cell types. Recent evidence indicates that connexins play a physiologically relevant role in the secretion of this endocrine gland [911]. The transcripts of at least three connexin isoforms (Cx36, Cx43, Cx45) have been repeatedly observed in extracts of intact pancreatic islets [12-14] and purified $\beta$-cell preparations derived thereof $[14,15]$. Immunolabeling studies have confirmed the expression of the Cx36 protein in the insulin-producing $\beta$-cells $[14,16]$, but have not provided definitive evidence for the presence of $\mathrm{Cx} 45$ [15], possibly due to the limited affinity and specificity of the currently available antibodies. Localization of the $\mathrm{Cx} 43$ protein in the pancreas has also been difficult. Thus, limited levels of this protein have been reported in normal rat islets after immunolabeling of pancreas sections and proteins $[13,17]$ and, accordingly, reduced numbers of $\beta$-cell gap junctions have been found in newborn $\mathrm{Cx} 43$-deficient mice [15], whereas $C x 43$ antisense oligonucleotides have been reported to reduce gap junctional conductance [18]. Conversely, an increase in Cx43 expression has been observed in rat neonatal islets exposed to hormonal conditions that promote the secretory maturation of $\beta$-cells [12]. Contrasting to these observations, it has been difficult to routinely reproduce the immunolabeling of $\mathrm{Cx} 43$ in mouse pancreatic islets [15]. Moreover, in spite of detectable electrical coupling between isolated $\beta$-cell pairs, electrical conductances characteristic of $\mathrm{Cx} 43$ and $\mathrm{Cx} 45$ could not be detected $[17,19]$. It is possible that these negative findings reflect the low expression of the proteins $[13,17]$, which may be close to the threshold levels for detection by immunofluorescence. Hence, it is still unclear whether $\mathrm{Cx} 43$ and $\mathrm{Cx} 45$ are actually expressed by $\beta$-cells or may be found in islets only under certain conditions. It is also not clear whether one of the two connexins may be restricted to portions of the $\beta$-cell membrane facing intra-islet vessels or adjacent duct cells. Answering to these questions is a basic prerequisite to elucidate the contribution of each connexin to islet functioning.

Immunolabeling is not the most appropriate approach to address these questions because it is dependent on the quality of the antibodies, and cannot resolve whether any connexin isoform is restricted to only one gap junction hemichannel or is expressed by both interacting cells. The interpretation of immunolabeling is further complicated when cells co-express low levels of multiple connexin isoforms or form small gap junction plaques, which is the case for pancreatic islet cells [20]. In situ hybridization studies can sometimes represent a useful alternative. However, they also are of limited use when multiple connexins are expressed at low levels and/or transiently. To bypass these limitations, we have designed the targeted replacement of several connexin genes by a lacZ reporter gene, which allows for a cell-autonomous monitoring of transcriptional activity at the level of individual cells $[21,22]$. Using general and cell-type restricted replacement of connexin coding DNA by lacZ reporter genes, we have now allocated to specific cell types the three connexins isoforms which have been reported in pancreatic islets [12-15]. The results show that $\mathrm{Cx} 36$ expression can be clearly attributed to the insulin-producing $\beta$-cells, but that of $\mathrm{Cx} 43$ and $\mathrm{Cx} 45$ cannot. Thus, in the pancreatic islets of our transgenic mice, expression of the two latter connexin isoforms was detected only between the endothelial cells of capillaries and vascular smooth muscle cells, respectively.

\section{Material and methods}

\section{Animals and cells}

The development of most transgenic mice used in this work has been previously reported. TIE2-cre mice express the Cre recombinase specifically in vascular endothelial cells, driven by regulatory elements of the tyrosine kinase in endothelium (TIE) 2 gene [22]. $\mathrm{Cx} 43^{\mathrm{fl}}$ mice carry a floxed $\mathrm{Cx} 43$ coding region that can be removed by cremediated recombination, leading to expression of an embedded lacZ gene encoding a nuclear $\beta$-galactosidase [22]. $\mathrm{Cx} 43^{\mathrm{del}}$ mice, generated by ubiquitous cre-mediated deletion of the floxed $C x 43$ gene elements carry a lac Z gene (encoding a nuclear $\beta$-galactosidase) in place of the $\mathrm{Cx} 43$ coding region [22]. $\mathrm{Cx} 45^{+-}$mice carry a lac $\mathrm{Z}$ gene (encoding a cytoplasmic $\beta$-galactosidase) in place of the $\mathrm{Cx} 45$ coding region [21]. Cx43-knock-in-Cx32(Cx43KI32-) and Cx43KI40 mice are heterozygous for a replacement of the $\mathrm{Cx} 43$ coding region by the coding region of Cx32 and Cx40, respectively [23]. Flox LacZ Indicator (FLZI) mice carry a silent lacZ gene (encoding a cytoplasmic $\beta$-galactosidase) under control of a ubiquitous promoter, in which lac $\mathrm{Z}$ expression is prevented by a floxed STOP sequence. Cre-mediated recombination removes the floxed STOP sequence, and lac Z expression serves as readout for Cre activity at the cellular level [24]. Rat InsulinII promoter- (INSPr)-Cre mice express the Cre recombinase in pancreatic $\beta$-cells [25]. $\mathrm{Cx} 43^{+/-}$ mice are heterozygous for a deletion of the $\mathrm{Cx} 43$ coding region and do not carry a reporter gene [26]. Mice carrying a targeted replacement of the Cx36-coding DNA by a lacZ gene encoding a cytoplasmic $\beta$-galactosidase $\left(\mathrm{C} \times 36^{\text {del }}\right.$ strain) were generated by a ubiquitous deletion of a floxed Cx36 allele (J.D., unpublished data), using a strategy similar to that used to produce $\mathrm{Cx} 43^{\mathrm{del}}$ mice [22]. Cx36 deletion in the germline was achieved after crossing $\mathrm{C} \times 36^{\mathrm{fl} /+}$ animals with Phosphoglycerate kinase promoter- (PGK-) Cre mice [27]. $\mathrm{C} \times 36^{\mathrm{del} /+}$ mice differ from previously described Cx36-deficient mice [28] by a targeted insertion of a lacZ reporter gene in exon 2 , leading to expression of a fusion protein comprising cytoplasmic $\beta$-galactosidase and 24-amino-acid residues of the Cx36 N terminus, encoded by exon 1. Pax4-cre- 
IRES-GFP mice were generated by ligating a $0.4-\mathrm{kb}$ genomic DNA fragment of the Pax4 promoter, known to mediate pancreatic expression [29] and to contain transcription factor binding motifs that are crucial for $\beta$ cell specific expression [30,31], to a construct allowing for a bicistronic expression of Cre recombinase and GFP. The construct was linearized and microinjected into pronuclei of fertilized FVB mouse oocytes, using standard procedures [32]. Transgenic lines were detected by their GFP expression.

Control rats of the OFA strain were used to prepare cultures of FACS-purified $\beta$-cell suspensions, as previously described [14].

\section{Genotyping}

Identification of wild type, heterozygous and homozygous littermates was performed as reported in previous publications $[21-25,33]$. Cx36 ${ }^{\text {del }}$ mice were genotyped by PCR using primers $5^{\prime}$-TGC ATT TGC CAG AGT AAA GGT GCG-3' and 5'-TTC TGT TTC AGC GCT TAC CAG TCC-3', a PCR buffer containing $1.5 \mathrm{mM} \mathrm{MgCl}_{2}$ and cycles of $1 \mathrm{~min}$ at $94^{\circ} \mathrm{C}$ and $2 \mathrm{~min}$ at $72^{\circ} \mathrm{C}$ (for both annealing and synthesis). These conditions generated a 330-bp Cx36 wildtype amplicon and a 220-bp $C \times 36^{\text {del }}$ amplicon.

\section{Immunolabeling and histochemistry}

Immunolabeling of connexins $\mathrm{Cx} 43, \mathrm{Cx} 40, \mathrm{Cx} 32$, Cx36 and insulin was carried out as previously reported $[14,15,23]$. For detection of EGFP immunoreactivity in Pax4-cre-IRES-GFP transgenic mice, the pancreas was fixed in $4 \%$ paraformaldehyde in PBS and embedded in paraffin. Sections were incubated with rabbit anti-EGFP antibodies (A6455, Molecular Probes, 1:400) followed by anti-rabbit-Alexa 488 (Molecular Probes, 1:500). Immunohistochemistry and 5-bromo-4-chloro-3-indolyl- $\beta$-galactoside (X-Gal) staining were performed as previously described [22]. Briefly, 10- $\mu \mathrm{m}$ cryosections of pancreas embedded in OCT compound were used. For comparative analysis, age-matched and sex-matched animals were chosen, and littermates were used whenever possible. An endogenous, senescence-associated $\beta$-galactosidase that is not localized in nuclei, and has optimal activity at $\mathrm{pH}$ 6.0, has been reported in endothelial cells [34]. In addition, an acid $\beta$-galactosidase activity has been detected in human fetal pancreas [35]. To control for both activities, pancreas sections from mice with and without lacZ reporter gene were processed in parallel, and care was taken to keep the reaction at $\mathrm{pH} 7.4$, which is optimal for the bacterial enzyme. Nonspecific $\beta$-galactosidase activity in the endocrine pancreas was not detected under these conditions, as previously reported in other tissues [21,22,36,37]. For X-Gal staining, sections were processed as previously described [24]. For doublelabeling immunohistochemistry, sections were stained overnight with $\mathrm{X}-\mathrm{Gal}$, as described above, exposed to PBS containing $0.1 \% \mathrm{H}_{2} \mathrm{O}_{2}$ and $10 \%$ methanol for 5-10 min, blocked in PBS containing 4\% BSA and then incubated for $1 \mathrm{~h}$ with the rat monoclonal MECA32 antibody (1:1000 dilution, Pharmingen) which recognizes a panendothelial antigen, followed by a peroxidase-conjugated donkey anti-rat IgG (Jackson Immunoresearch) for $45 \mathrm{~min}$ at room temperature. Development of the product of the peroxidase reaction was carried out using 3,3'diaminobenzidine tetrahydrochloride (Sigma) as a substrate. In a second set of double-labeling experiments, we used the MECA32 antibody (1:800, Pharmingen) and an $\alpha$ smooth muscle actin antibody (mouse monoclonal, Sigma, 1: 200), respectively. As secondary antibodies, we used biotin-coupled donkey anti-rat IgGs (Dianova, 1:200) and biotinylated goat anti-mouse IgGs (1: 250, M.O.M. Kit, Vector Laboratories Inc., Burlingame), respectively. Immunohistochemistry was performed using the M.O.M. kit, according to manufacturer's instructions.

\section{$\beta$-cell sorting}

Enrichment of rat $\beta$-cell suspensions by FACS was performed as reported [14]. Briefly, islets of Langerhans were isolated from the exocrine pancreas by collagenase digestion and purification on a histopaque gradient. Single cells were then isolated by trypsinization, and $\beta$-cells were sorted from the other islet cell types as a function of both flavin adenine dinucleotide (FAD) autofluorescence (510$550 \mathrm{~nm}$ ) and forward light scatter.

To improve the enrichment of the $\beta$-cell fraction, we further used pancreatic islets of adult Pax4-cre-IRES-GFP mice. Islet cells were isolated as previously described [14]. Single $\beta$-cells were then sorted from the nonlabeled mixture of all other islet cell types, as a function of GFP fluorescence. To obtain a highly pure fraction of $\beta$-cells, the FACS selection window was restricted to cells displaying high levels of GFP fluorescence.

$R N A$ extraction and amplification by reverse transcriptasepolymerase chain reaction (RT-PCR)

RNAs were extracted from purified $\beta$ - and non- $\beta$-cells using the RNeasy micro kit (Qiagen), as recommended by the manufacturer. The extraction protocol included an RNAse-free DNAse I step to avoid contamination by genomic DNA. Aliquots (50 ng each) of total RNA were reverse-transcribed into first-strand cDNA, using Sensiscript reverse transcriptase (Qiagen) and random primers, according to the manufacturer's instructions. Ten microliters aliquots of cDNA were used for subsequent PCR which was performed in $60 \mu \mathrm{l}$ PCR mix containing $0.1 \mathrm{U}$ Taq polymerase (Finnzymes, Espoo, Finland), $1.5 \mathrm{mM}$ $\mathrm{MgCl}_{2}, 250 \mu \mathrm{M}$ dNTPs, $0.2 \mu \mathrm{M}$ each primer and $1 \times$ PCR buffer. PCR reaction was carried out using a $\mathrm{T}$ Gradient Thermocycler 96 (Biometra GmbH, DE). The 
following primers were used: $\mathrm{Cx} 32$ forward 5'-AGT GCC AGG GAG GTG TGA AT-3', reverse 5'-GGA ACA CCA CAC TGA TGA CA-3' (expected amplicon: 452 bp); Cx36 forward 5'-GAG CCC AGG CCA AGA GGA AGT C-3', reverse 5'-GGC ATG CTG AAG GGG GAG AAA T-3' (expected amplicon: $559 \mathrm{bp}$ ); Cx43 forward 5'-CGG CGG CTT CAC TTT CAT TA-3', reverse 5'-AGA ACA CAT GGG CCA AGT AC-3' (expected amplicon: 334 bp); Cx45 forward 5'-GGG CAA ACC AAT TCC ACC ACC-3', reverse 5'-CTC GTT TGG GAT ACG GTA CGC-3' (expected amplicon: $379 \mathrm{bp}$ ); insulin forward $5^{\prime}$-TGC CCA GGC TTT TGT CAA ACA GCA CCT T- ${ }^{\prime}$, reverse 5'-CTC CAG TGC CAA GGT CTG AA-3' (expected amplicon $188 \mathrm{bp}$ ) and $\beta$-actin forward $5^{\prime}$-CGT GGG CCG CCC TAG GCA CCA G $-3^{\prime}$, reverse 5'- TTG GCC TTA GGG TTC AGG GGG G -3' (expected amplicon 243 bp for cDNA and $330 \mathrm{bp}$ for genomic DNA). The thermal cycle profile used for amplification was $94^{\circ} \mathrm{C}$ for $1 \mathrm{~min}$, $58^{\circ} \mathrm{C}$ for $1 \mathrm{~min}$ and $72^{\circ} \mathrm{C}$ for $1 \mathrm{~min}$, during 35 cycles. For $\beta$-actin, the melting temperature was $70^{\circ} \mathrm{C}$. PCR products were resolved by $2 \%$ agarose gel electrophoresis and visualized by ethidium bromide staining.

\section{Results}

RT-PCR indicates a differential cell-type distribution of Cx36 compared to Cx43 and Cx45

Transcripts for $\mathrm{Cx} 43$ and $\mathrm{Cx} 45$ are detected by RTPCR in both $\beta$ - and non- $\beta$-cell fractions of FACS purified preparations of rat islet cells. These preparations were not contaminated by remnants of exocrine pancreas, as indicated by the lack of amplification of Cx32 (Fig. 1A), but, in spite of a high purity, could not avoid some cross-contamination by unwanted islet cell types. Since this minimal contamination prevented an unambiguous interpretation of the RT-PCR data, we performed a FACS separation of $\beta$-cells expressing GFP in mice carrying a Pax4-cre-IRES-GFP transgene (Fig. 2A). In adult mice, GFP expression was confined to islet cells that had the numerical and topographical distribution characteristic of $\beta$-cells (Fig. 2B). To generate a highly pure fraction of $\beta$-cells, the parameters of the FACS separation were set to select only those cells featuring a high GFP fluorescence, at the expense of purity in the non- $\beta$-cell fraction,
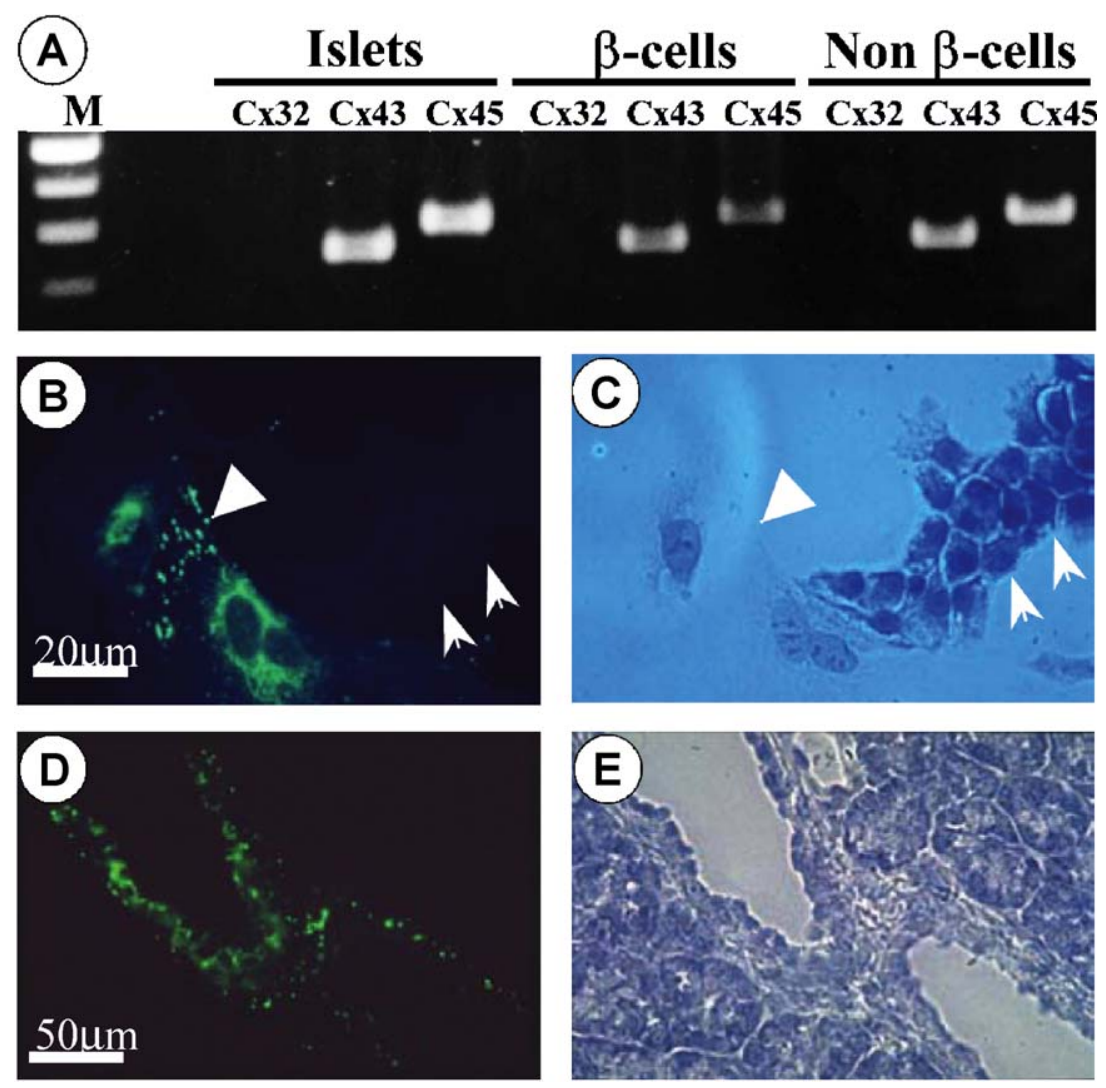

Fig. 1. Cx43 and Cx45 are expressed in FACS purified $\beta$ - and non- $\beta$-cell populations of rat islets. (A) RT-PCR analysis shows that $\mathrm{Cx} 43$ and $\mathrm{Cx} 45 \mathrm{mRNAs}$ are expressed in isolated pancreatic islets, as well as in FACS-purified $\beta$ - and non- $\beta$-cell populations isolated thereof. In contrast, no transcript for Cx32 was found in either islets or islet cells, indicating absence of significant contamination by remnants of exocrine pancreas. (B, C) In monolayer cultures, Cx43 (arrowhead) was immunolabeled between fibroblasts but not primary islet cells (arrows). (D) Cx43 was also detected in situ between fibroblasts surrounding interlobular pancreatic ducts. Scale bar: $20 \mu \mathrm{m}$ in B and C, and $50 \mu \mathrm{m}$ in D and $\mathrm{E}$. 


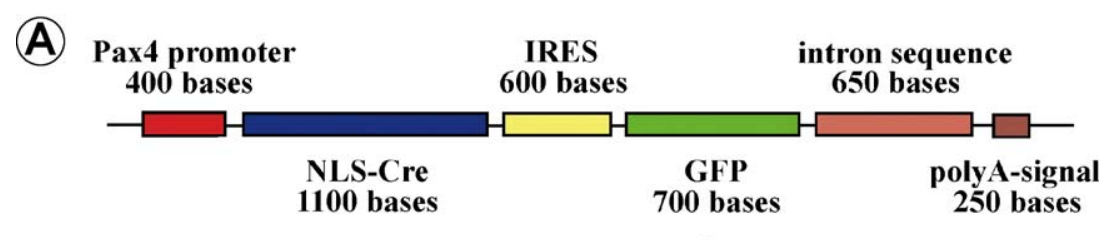

(B)
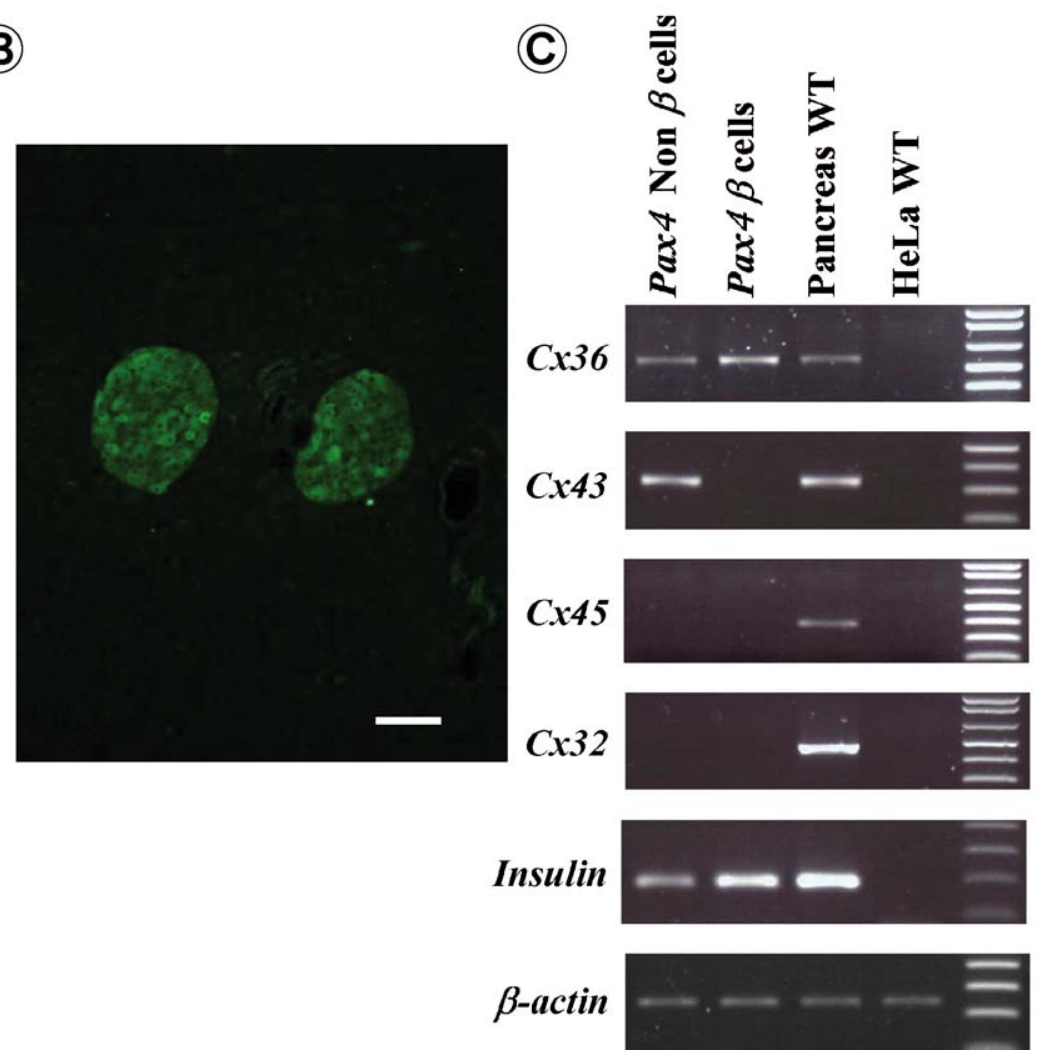

Fig. 2. Cx43 transcripts are not detected in highly purified populations of mouse $\beta$-cells. (A) Schematic view of the transgenic construct driving GFP expression in pancreatic $\beta$-cells. Pax4 gene regulatory elements drive bicistronic expression of Cre recombinase and GFP. Bp, base pairs; IRES, internal ribosome entry site; NLS, nuclear localization sequence; polyA, polyadenylation. (B) Immunofluorescence of pancreatic section shows confinement of GFP to most islet $\beta$-cells. Scale bar: $50 \mu \mathrm{m}$. (C) FACS purification based on GFP fluorescence was followed by RT-PCR analysis of transcripts for Cx36, Cx43, Cx45, $\mathrm{Cx} 32$, insulin and $\beta$-actin. Cx32 was only detected in whole pancreas, indicating absence of exocrine cells in the purified fractions. Transcripts for insulin were also found in non- $\beta$-cell populations, indicating some contamination of this fraction by $\beta$-cells featuring low GFP fluorescence. Consistently, Cx36 was detected in all pancreatic samples. In contrast, $\mathrm{Cx} 43$ was not detected in the highly purified $\beta$-cell fraction, but was easily detected in both the non- $\beta$-cell population and whole pancreas. Cx45 was found in whole pancreas but not in the purified islet cell fractions, presumably due to low expression levels. Right lanes: molecular mass marker.

which became contaminated by those $\beta$-cells featuring low levels of GFP fluorescence, as indicated by the finding of both insulin and Cx36 transcripts (Fig. 2C). On the other hand, the $\beta$-cell fraction was likely to be essentially devoid of contaminating cells. Consistent with this separation protocol, a Cx36 transcript was detected in both the $\beta$ - and the non- $\beta$-cell fraction (Fig. $2 C$ ). In contrast, no $\mathrm{Cx} 43$ transcript was found in the purified $\beta$ cell fraction (Fig. 2C), confirming the view that the transcript observed in the less purified rat $\beta$-cell fractions (Fig. 1) reflected a contamination by unwanted cell types. Accordingly, parallel immunolabeling experiments failed to reveal $\mathrm{Cx} 43$ in FACS-purified cultures of primary rat $\beta$-cells, using antibodies which, in the very same cultures, resulted in the staining of contaminating fibroblasts
(Figs. 1B, C). The latter cells also expressed $\mathrm{Cx} 43$ in the intact pancreas, particularly around interlobular ducts (Figs. 1D, E).

Cx45 was not detectable in either the $\beta$ - or the non- $\beta$-cell fraction (Fig. 2C), probably due to lower $\mathrm{Cx} 45$ levels and yield of cells after FACS purification in mouse (Fig. 2) compared to rat (Fig. 1). Our data indicated that $\mathrm{Cx} 36$ is expressed in $\beta$-cells, whereas $\mathrm{Cx} 43$ is likely to be expressed in non- $\beta$-cells. Because we could not detect $\mathrm{Cx} 45$ using RTPCR of purified cell fractions from mouse islets, we decided to perform a highly sensitive reporter gene approach, using lac $\mathrm{Z}$ expression monitoring transcriptional activity of connexin genes. As a further benefit, this approach allowed us to examine connexin expression in situ in a cell-autonomous manner. 


\section{Cx36 is expressed by insulin-producing $\beta$-cells}

We crossed $\mathrm{Cx} 36^{\mathrm{fl} /+}$ mice with PGK-Cre mice to delete the floxed gene elements and activate the embedded lac $\mathrm{Z}$ gene, under control of the regulatory elements of the endogenous Cx36 gene. The offspring was backcrossed with $\mathrm{C} 57 \mathrm{BL} / 6$ mice to remove the Cre transgene and to generate a colony of $\mathrm{Cx} 36^{\mathrm{del} /+}$ mice (Fig. 3A). In these mice, which were heterozygous for the targeted replacement of the Cx36-coding region (exon 2) by the reporter gene, XGal staining of pancreas sections revealed that the transcriptional expression of the reporter gene was confined to the endocrine islets, and particularly to their central region, which consists mostly of $\beta$-cells (Fig. 3B). Accordingly, immunolabeling with a variety of antibodies to $\mathrm{Cx} 36$, which yielded identical results, revealed the protein at discrete areas of islet cell membranes (Fig. 3C), which were positively identified as $\beta$-cells by immunostaining of their insulin content (Fig. 3D).

\section{Cx43 is detected in endothelial cells but not in $\beta$-cells of} pancreatic islets

We determined the pattern of lacZ expression in $\mathrm{Cx} 43^{\mathrm{fl} /+}$, INSPr-Cre mice, in which the $\mathrm{Cx} 43$ coding region is deleted in $\beta$-cells. No expression of the lacZ gene, monitored to report on the transcriptional activity of the $\mathrm{Cx} 43$ gene, was detected in the endocrine islet cells (Fig. 4A). Because the INSPr-Cre transgene mediated an efficient deletion of floxed DNA in $\beta$-cells, as judged by lacZ expression in the endocrine pancreas of FLZI mice (Fig. 4B), the data suggest that lack of $C x 43$ gene activity in $\beta$ cells is the most likely explanation for the absence of reporter gene expression in $\mathrm{Cx} 43^{\mathrm{fl} /+}$, INSPr-Cre mice. To further substantiate this finding, total transcriptional activity of $C x 43$ was assessed in the pancreas of $\mathrm{Cx} 43^{\mathrm{del} /+}$ mice, which feature a general deletion of the floxed $\mathrm{Cx} 43$-coding region. Within pancreatic islets, nuclear X-gal staining was found predominantly in cells that were positive for the endothelial cell marker MECA32, as judged by the colocalization of the brown-colored MECA32 signal with the blue X-gal stain (Fig. 4C, center). Note that Cx43 expression did not occur in all endothelial cells of islets. In the exocrine tissue bordering the islets, lac Z expression was also found in other cell types aside from endothelial cells (Fig. 4C, top center). In $\mathrm{Cx} 43^{\mathrm{fl} /+}$, TIE2-cre mice, which feature an endothelium-specific deletion of the $C x 43^{f l}$ allele, most of the X-Gal staining also colocalized with the endothelial marker MECA32 in both the exocrine [22] and endocrine parts of pancreas (Fig. 4D), with a pattern similar to that observed in $C x 43^{\mathrm{del} /+}$ mice (Fig. 4C). Thus, based on X-gal staining, Cx43 expression in pancreatic islets is attributable only to endothelial cells. Accordingly, no obvious immunolabeling of $\beta$-cells was observed in
(A)
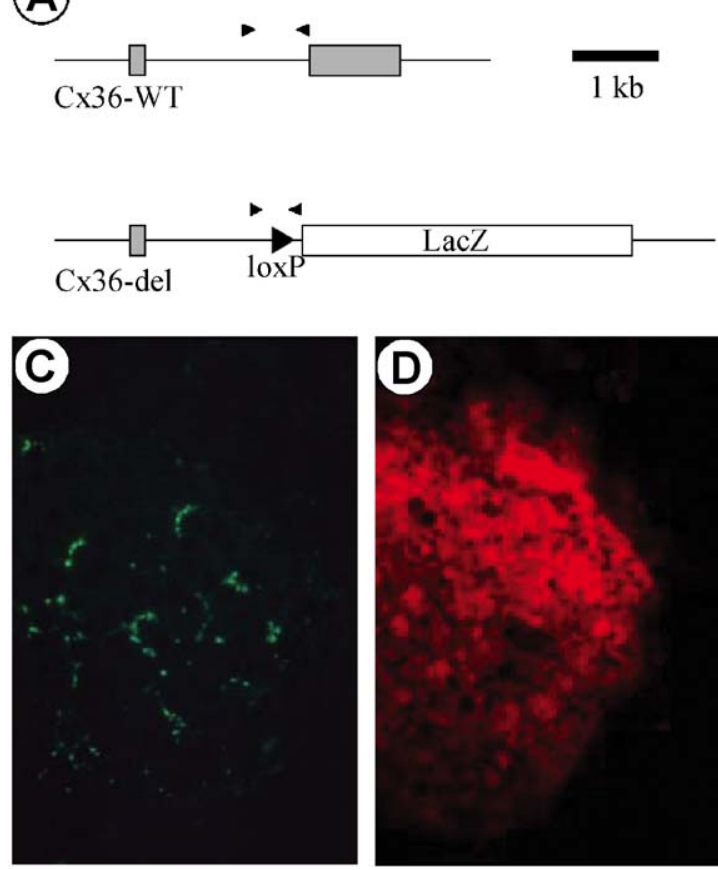
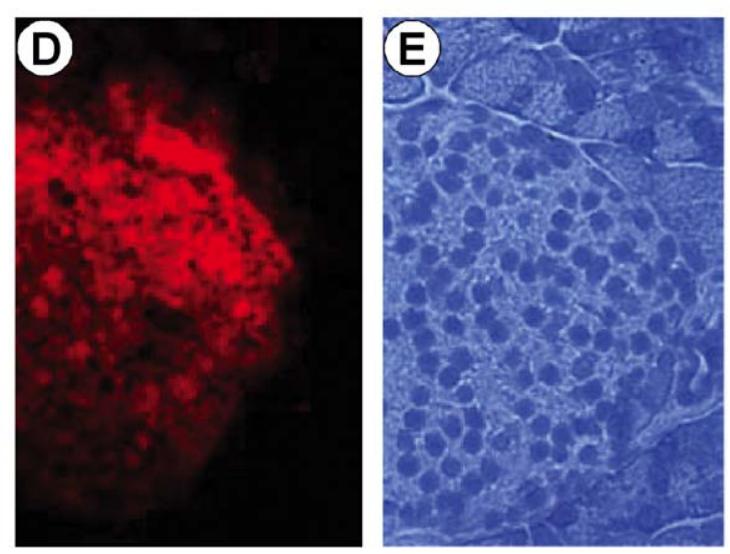

Fig. 3. Cx36 is expressed by islet $\beta$-cells. (A) Scheme of the targeted (Cx36-del) and wild-type (Cx36-WT) Cx36 locus. A lacZ gene (white box) was targeted in place of the portion of the Cx36 coding region in exon 2, leading to the expression of a fusion protein with the N terminus of Cx36. Grey boxes: Cx36 exonic DNA. Triangle: loxP site. Arrowheads: primers used for genotyping. (B) X-gal staining of a pancreatic cryosection from a Cx36 ${ }^{\mathrm{del} /+}$ mouse shows labeling of numerous $\beta$-cells in the center of an endocrine islet. (C) Immunolabeling with an antibody against Cx36 revealed a punctate decoration of cell membranes, predominating in the center of a pancreatic islet. (D) Immunostaining of the same section with an antibody to insulin, positively identified the Cx36-expressing cells as fully differentiated $\beta$-cells. (E) Phase-contrast view of the field illustrated in C and D. Scale bar: $50 \mu \mathrm{m}$ in B and $30 \mu \mathrm{m}$ in C, D and E. 

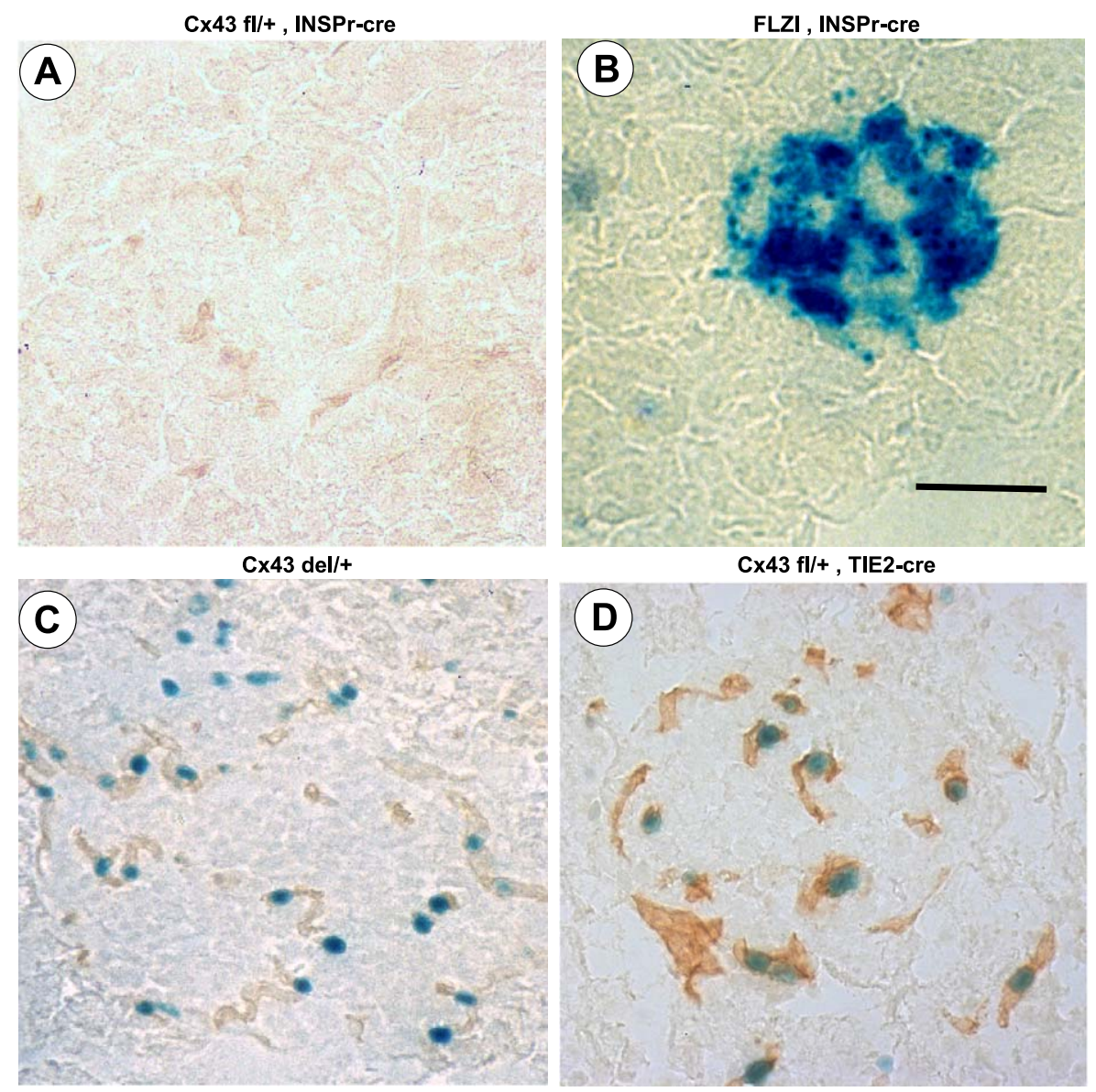

Fig. 4. Cx43 gene-driven lacZ expression is detected in islet vessels but not in $\beta$-cells. (A, C, D) Combined X-gal staining (blue) and immunolabeling of MECA32 (brown). In islets from $\mathrm{Cx} 43^{\mathrm{fl} /+}$, INSPr-Cre mice with deletion of $C x 43$ in endocrine insulin-producing cells, no X-gal staining was observed (A). In contrast, endocrine islet cells showed an intense X-Gal staining in mice transgenic for both the INSPr-Cre and the FLZI transgene (B), indicating that the negative findings illustrated in A could not be attributed to lack of activity of the INSPr-Cre transgene. Expression of the lacZ reporter gene embedded in the Cx43 locus was detected in thread-like structures that had the topographical arrangement of vessels and were positive for the endothelial antigen MECA32, in islets of $\mathrm{Cx} 43^{\mathrm{del} /+}$ mice (C). A similar staining was observed in islets of $\mathrm{Cx} 43^{\mathrm{fl} /+}$, TIE2-cre mice (D), in which $C x 43$ was specifically deleted in endothelial cells. In no case was a lacZ staining observed in the endocrine cell types which form most of the islet mass (A, C and D). Scale bar: $35 \mu \mathrm{m}$.

wild-type mice using a variety of antibodies to Cx43 (Figs. $5 \mathrm{~F}, \mathrm{I})$. In contrast, the same antibodies resulted in a sparse Cx43 labeling of some islet cells within adult islets that had an endothelial topography, that is, were arranged in long strings of immunoreactive puncta (Figs. 5F, I). Similar observations were made in islets of mice obtained by interbreeding $\mathrm{Cx} 43^{+/-}$, INSPr-cre mice with $\mathrm{Cx} 43^{\mathrm{fl} / \mathrm{fl}}$ animals, which yielded among the offspring several $\mathrm{Cx} 43^{\mathrm{fl} /}$ INSPr-cre mice lacking the $\mathrm{Cx} 43$ coding region only in pancreatic $\beta$-cells (not shown). High-resolution analysis of double-labeling immunohistochemistry (Fig. 5A) using MECA32 antibodies to identify endothelial cells (brown) and X-gal to visualize $C x 43$ expression (blue) gave results analogous to those obtained by double-label immunofluorescence (Fig. 5B) for Cx43 (red) and MECA32 (green). Thus, $\mathrm{Cx} 43$ was located exclusively in small islet vessels. Additional immunofluorescence of medium-sized vessels of exocrine pancreas (Fig. 5C) showed $\mathrm{Cx} 43$ (red) at endothelial membranes (green), but not between smooth muscle cells, characterized by elongated nuclei (blue), of the same vessels (Fig. 5D). Omission of the primary antibodies directed to $\mathrm{Cx} 43$ and MECA32 did not lead to significant labeling (Fig. 5E).

To exclude an interference of the bacterial lac $\mathrm{Z}$ sequence on the transcription of $C x 43$ in $\beta$-cells, we prepared sections of pancreas from heterozygous "knockin" mice of the Cx43KI40 (Figs. 5G, J) and Cx43KI32 lines (Figs. 5H, K), which use the endogenous $C x 43$ gene regulatory elements to direct the expression of $\mathrm{Cx} 40$ and Cx32, respectively. Using antibodies which detected these two connexins in cardiomyocytes of $\mathrm{Cx} 43 \mathrm{KI} 40$ and Cx43KI32 mice [23], we did not observe expression of these two additional reporter genes in either $\beta$-cells or intra-islet vessel cells. Absence of $\mathrm{Cx} 40$ or $\mathrm{Cx} 32$ immunoreactivity in vessels was due to lower numbers of knock-in specimens screened compared to wild-type specimens, where we occasionally found $\mathrm{Cx} 43$ immunoreactivity in intra-islet vessels. 

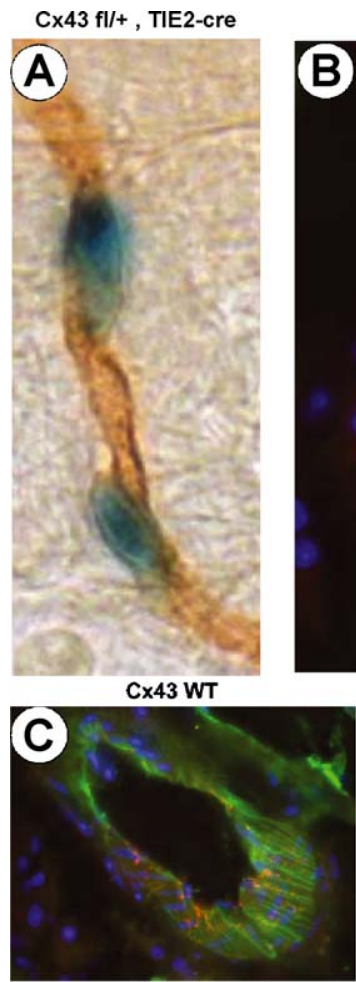

Cx43 WT

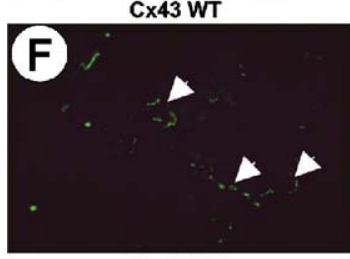

Cx43 WT

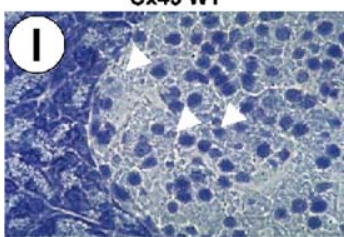

CX43 WT

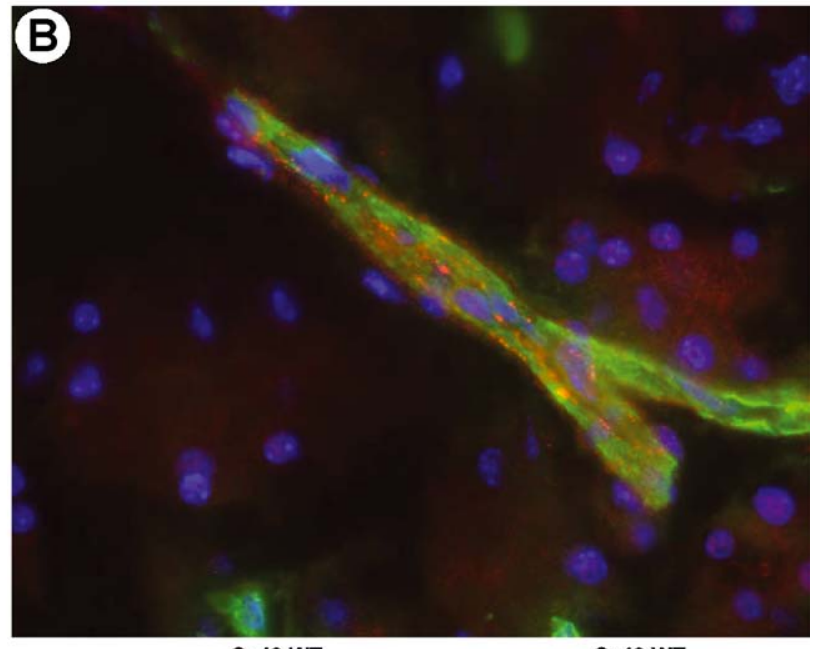

Cx43 WT

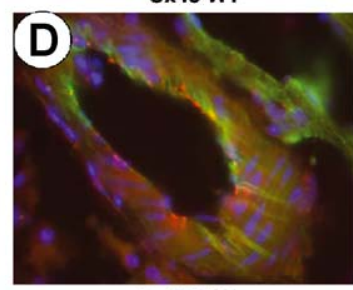

$\mathrm{C} \times 43 \mathrm{~K} 140$

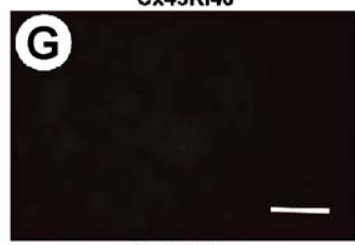

CX43KI40

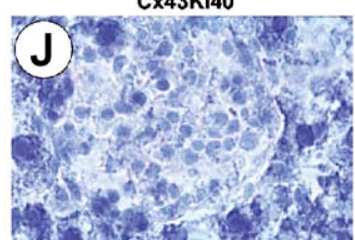

Cx43 WT
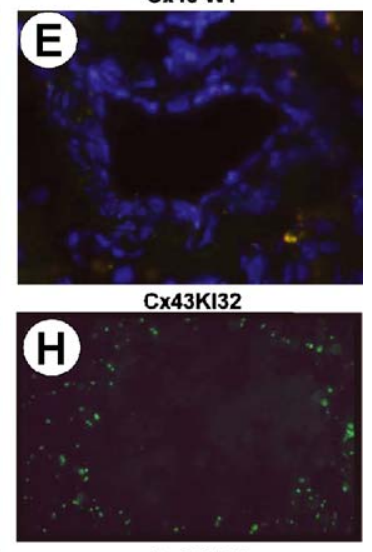

Cx43KI32

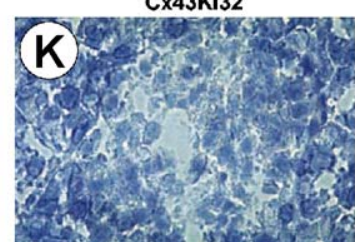

Fig. 5. Cx43 protein connects endothelial cells but not $\beta$-cells of rodent pancreas. (A) The lacZ expression (blue) in islets is colocalized with MECA32 expression (brown). At high magnification, the localization of $\beta$-galactosidase in the nuclei of endothelial cells is obvious. (B) Likewise, punctate Cx43 antibody staining (red) colocalizes with MECA32-positive cell membranes of endothelial cells (green), featuring a spacing of typically ellipsoid nuclei (blue), as seen in A. (C) In larger vessels, Cx43 and MECA32 signals (green) were found in endothelial cells, whose nuclei (blue) are round or ellipsoid. (D) Another focal plane, showing the much more elongated nuclei (blue) of smooth muscle cells, reveals neither MECA32 (green) nor Cx43 immunoreactivity (red) in the muscular layer of the vessel. (E) Negative control obtained by omitting the primary antibodies. (F, I) On rare occasions, sparse Cx43 labeling was detected by immunofluorescence along some intra-islet vessels. (G, J) Immunostaining of islets from heterozygous Cx43KI40 mice failed to detect any $\mathrm{Cx} 40$, which was expected at sites endogenously expressing Cx43. (H, K) Similarly, immunolabeling of islets from heterozygous $\mathrm{Cx} 43 \mathrm{KI} 32$ mice, using antibodies that detected endogenous $\mathrm{Cx} 32$ between the acinar cells of exocrine pancreas, did not result in labeling of endocrine islets. I, J and $\mathrm{K}$ are the phase-contrast views of the fields illustrated in $\mathrm{F}$, $\mathrm{G}$ and $\mathrm{H}$, respectively. Scale bar in G: $10 \mu \mathrm{m}$ in $\mathrm{A}$ and $\mathrm{B}$, $20 \mu \mathrm{m}$ in $\mathrm{C}-\mathrm{E}$ and $40 \mu \mathrm{m}$ in $\mathrm{F}-\mathrm{K}$.

\section{Cx45 is distributed similar to Cx43}

To analyze the expression of $C x 45$, we performed X-gal staining of pancreas cryosections from $\mathrm{Cx} 45^{+/-}$mice, in which the reporter gene replaced the connexin-coding region [21]. Cx45 expression was detected in islet vessels, particularly close to exocrine tissue (Fig. 6A), and was much less prominent in the center of the islets (Fig. 6C). We also found vessel-associated $C x 45$ expression in capil- laries (Fig. 6E) and medium-sized vessels of exocrine pancreas (Fig. 6F). However, the X-gal staining, reflecting the distribution of $\mathrm{Cx} 45$, did not fully overlap with the immunolabeling for MECA32, which reflects the position of endothelial cells (Figs. 6A, C, E, F), suggesting that $\mathrm{Cx} 45$ may be expressed by vascular cells closely apposed to endothelial cells. Accordingly, lacZ expression colocalized with immunoreactivity for the smooth muscle and pericyte marker $\alpha$ smooth muscle actin (Fig. 6D). In large pancreatic 


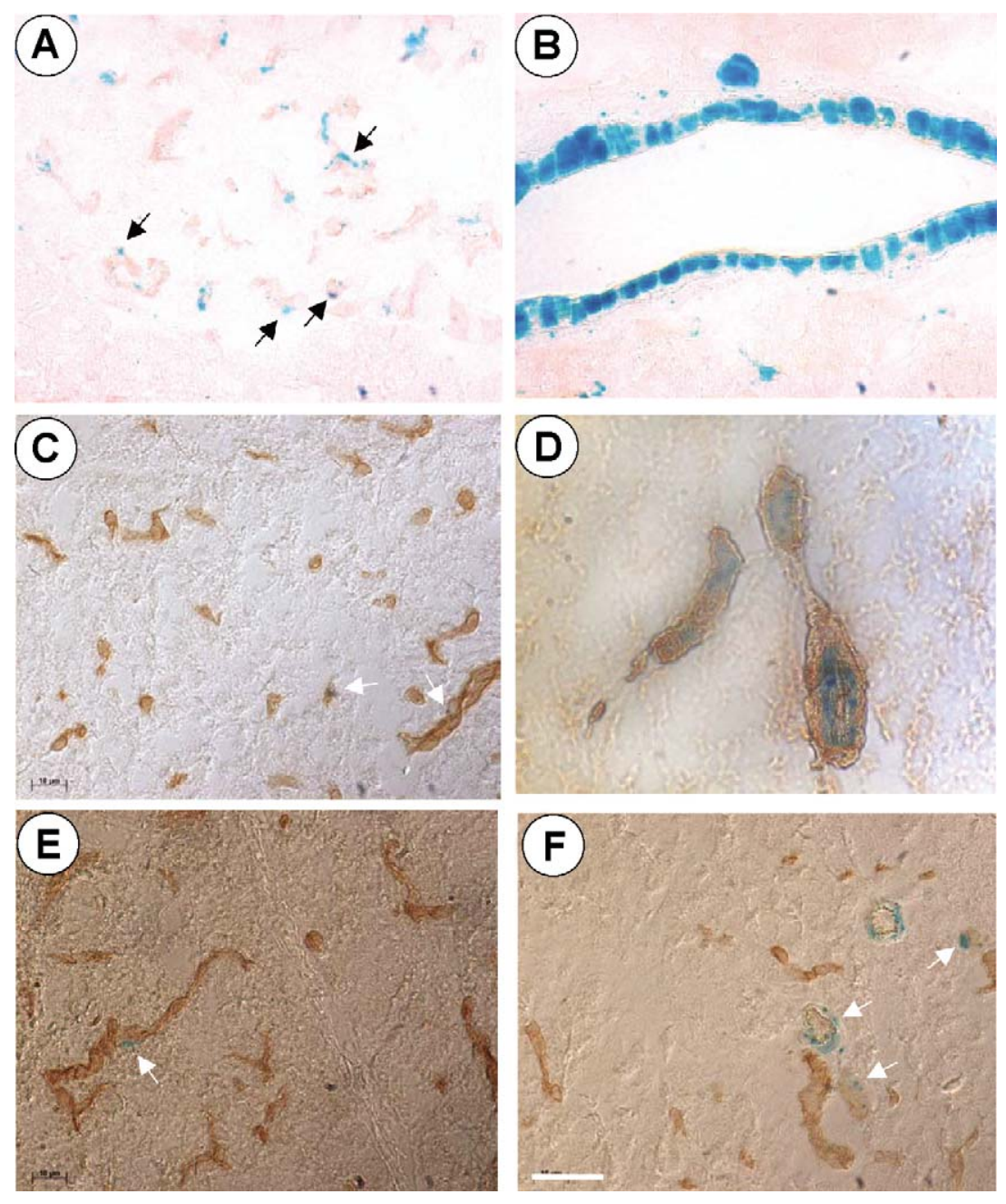

Fig. 6. Cx45 is expressed in smooth muscle cells of large vessels and colocalizes with $\alpha$ smooth muscle actin but not with MECA32 in smaller vessels. Combined X-gal staining (blue) and immunolabeling of MECA32 (brown, A-C, E, F) or $\alpha$ smooth muscle actin (D, brown) in pancreas of Cx45 ${ }^{+/-}$mice. Expression of the lac Z gene, embedded in the Cx45 locus, was readily detected in small intra-islet vessels bordering exocrine tissue (A), but was less apparent in capillaries in the center of pancreatic islets (C) or in exocrine tissue (E). Labeling was always juxtaposed to, but not overlapping with the MECA32 staining (arrows in A, C, E, F). Cx45 was strongly expressed in smooth muscle cells of arteries within the interlobular spaces of exocrine pancreas (B). The lacZ expression for $C x 45$ also occurred in $\alpha$ smooth muscle actin positive cells of smaller vessels (D). No X-Gal staining was detected in the endocrine cells of islets (A, C). Scale bar in F: $10 \mu \mathrm{m}$ for A, B, C, E and F, and $50 \mu \mathrm{m}$ for D.

arteries, it was clear that the $C x 45$ gene was expressed by smooth muscle cells (Fig. 6B). The cytoplasmic localization of $\beta$-gal expressed lead to a staining of the whole cells when the lacZ reporter gene was strongly expressed (Fig. 6B), and to a punctate staining when lacZ was expressed at lower levels (Fig. 6A; [21]).

\section{Discussion}

We have employed a strategy of either general or cellspecific replacement of endogenous genes by a reporter sequence to map the transcriptional activity of three connexin genes within pancreatic islets. We have found that the lacZ approach permitted to detect an obvious expression of the $C x 36$ gene in insulin-producing $\beta$-cells. These findings provide novel evidence for the prominent expression of this connexin isoform in $\beta$-cells of the mouse pancreas, confirming, in a highly sensitive and cell-autonomous manner, the indications previously given by immunolabeling of both primary islet cells from rat [14] and tumoral insulin-producing cell lines [11]. The functional reason for this specificity remains to be clarified. Recent observations indicate that loss of Cx36 alters the acute, in vitro stimulation of insulin secretion by both metabolizable and non-metabolizable secretagogues, as well as the synchronization of secretagogue-induced $\mathrm{Ca}^{2+}$ transients in insulin-producing MIN6 cells [11]. Studies on transgenic mice, which feature a global deficiency in $C x 36$ [28,38], indicate that these effects also take place under in vivo conditions (P.M., unpublished data).

In view of the usual co-expression of multiple connexin isoforms by most cell types [1] and of previous work indicating the presence of $\mathrm{Cx} 43$ and, possibly, $\mathrm{Cx} 45$ in 
pancreatic islets $[13,15]$, we have used the same lacZ approach, in both a general and a conditional manner, to investigate the intra-islet expression of these two connexins. We have observed the activity of the lac $\mathrm{Z}$ reporter gene in a variety of organs known to express high levels of either $\mathrm{Cx} 43$ or $\mathrm{Cx} 45$, indicating the proper function of the targeted lacZ genes [21,22,36,37]. Intriguingly, however, no activity of the reporter gene, reflecting the translation of either $\mathrm{Cx} 43$ or $\mathrm{Cx} 45$, was detected in the pancreatic $\beta$-cells of the very same animals. Absence of lac $Z$ expression in $\beta$-cells of $\mathrm{Cx} 43^{\mathrm{fl} /+}$, INSPr-cre mice could indicate the inability of the lac Z reporter construct to accurately report on the expression of the targeted gene, which is expressed at low levels within rat pancreatic islets [13]. In favor of this possibility, alterations in the endogenous activity of some housekeeping genes have been observed after insertion of lacZ sequences [39]. However, such an effect was clearly not observed in our study when the lacZ reporter gene replaced the Cx36 coding region. Furthermore, two other reporter genes $(C \times 32$ and $C x 40$ ) also failed to provide evidence for the expression of $\mathrm{Cx} 43$ in $\beta$-cells of $\mathrm{Cx} 43 \mathrm{KI} 32$ and Cx43KI40 mice [23], respectively, consistent with records of gap junctional conductance in pairs of $\beta$-cells, which have failed to show electrical characteristics typical for $\mathrm{Cx} 43$ and $\mathrm{Cx} 45$ channels $[17,19]$. Furthermore, it has been proven difficult to obtain a specific and reproducible immunolabeling of $\beta$-cell membranes using a variety of antibodies to $\mathrm{Cx} 43$. This finding, however, was challenged by observations in rat islets [12]. Our data certainly rule out that $\mathrm{Cx} 43$ is a prominent connexin isoform in most $\beta$-cells and show that the $C x 43$ transcript is mostly present in other cell types. This view is consistent with the RT-PCR data showing the presence of this transcript in the "non- $\beta$-cell" fraction of FACS-separated islet cells, but not in a highly purified fraction of GFPexpressing $\beta$-cells. Our data do not exclude the possibility that limited amounts of $\mathrm{Cx} 43$ might be expressed by a subset of $\beta$-cells with either a small size or low Pax4 expression which may contaminate the "non- $\beta$-cell" fraction $[40,41]$. In this perspective, the finding of lacZ expression in pancreatic ducts and in limited portions of the intraislet capillary network, two locations where undifferentiated and differentiated insulin-producing cells closely interact with other cell types $[42,43]$, raises the intriguing possibility that $\mathrm{Cx} 43$ may be selectively expressed at sites where $\beta$-cell membranes are apposed to duct or vascular cells. A contribution of connexin-dependent contacts between endocrine and vascular cells has been recently demonstrated in another endocrine system [8].

Similar observations were made concerning the distribution of the lacZ staining expected to reflect the site of expression of $\mathrm{Cx} 45$. Cx45 gene-driven lac $\mathrm{Z}$ expression was always vessel-associated. It was sparse in the dense capillary network at the center of pancreatic islets, and more prominent at islet borders facing the exocrine tissue, where there is a higher density of medium-sized vessels. The labeling in capillaries and medium-sized vessels was juxta- posed to, but not overlapping with the endothelial marker MECA32. In medium-sized vessels, lacZ expression clearly colocalized with $\alpha$ smooth muscle actin, a marker of pericytes and smooth muscle cells. In large vessels of exocrine pancreas, lac $Z$ expression clearly occurred in smooth muscle cells, as previously reported in other tissues [21]. Our data clearly show that most of $\mathrm{Cx} 45$ was not expressed by the majority of $\beta$-cells. Accordingly, the considerations made above regarding $\mathrm{Cx} 43$ expression also apply to this case. Thus, it remains to be investigated whether these findings reflect a limitation in the sensitivity of the reporter gene analysis, or the actual absence of the Cx45 protein in the insulin-producing cells of the islets. A definitive answer to this question is presently precluded by the very small size of $\mathrm{Cx} 45$ containing gap junction plaques [44], and the relative insensitivity of the $\mathrm{Cx} 45$ antibodies (K.W., unpublished observations).

In contrast to the abovementioned negative findings, clear lacZ expression was observed in ducts and large vessels of the pancreas in the very same $\mathrm{Cx} 43^{\mathrm{del} /+}$ and $\mathrm{Cx} 45^{+/-}$mice. $\mathrm{Cx} 43$ expression was found in epithelial duct cells of the exocrine pancreas [36], in fibroblasts surrounding interlobular ducts and in endothelial cells of arterioles and veins, whereas $\mathrm{Cx} 45$ expression was assigned to smooth muscle cells of arterioles. Interestingly, $\mathrm{Cx} 45$ has been previously assigned to fibroblastic cells around pancreatic ducts and vessels, as well as to epithelial cells of intra- and interlobular ducts [15], using $\mathrm{Cx} 45$ antibodies that might cross-react with $\mathrm{Cx} 43$. Since this distribution mimicked the lac Z expression pattern in $\mathrm{Cx} 43^{\mathrm{del} /+}$ mice, our findings on reporter gene expression agree with the observed immunolabeling of the cognate proteins under both in vitro and in vivo conditions $[15,21,22,36]$. Thus, the use of reporter genes is a valid approach and matches the expression pattern determined by immunodetection, when proteins are expressed at sufficiently high levels. A much less intense staining, with a pattern recalling the topography of small vessels, was also seen within the endocrine islets. In this case, the lac Z expression, assumed to reflect $\mathrm{Cx} 45$, appeared restricted to vascular cells that are juxtaposed to, but not overlapping with, the immunostaining of the endothelial marker MECA32 and was found in $\alpha$ smooth muscle actin positive cells, which is a marker for smooth muscle and pericytes. Our findings in pancreas and the previously described widespread expression of $\mathrm{Cx} 45$ in vascular smooth muscle cells [21] suggest that $\mathrm{Cx} 45$ is mostly expressed by cells of the vascular wall but not in endothelial cells. The lac $\mathrm{Z}$ expression indicating $C x 43$ gene activity was more extensive than the immunofluorescence labeling of the cognate $\mathrm{Cx} 43$ protein. It is likely that, as reported in other systems, this reflects the higher sensitivity of the reporter gene analysis versus that of immunofluorescence $[21,22]$. In fact, the absence of islet staining observed in Cx43KI32 and Cx43KI40 mice also indicates that other connexin-coding regions (such as $\mathrm{Cx} 32$ and $\mathrm{Cx} 40$ ) are not adequate reporters of $\mathrm{Cx} 43$ translation in cells expressing 
low levels of the protein. Limited expression of $\mathrm{Cx} 43$ and Cx45 in islet fibroblasts and vessels, at levels below the threshold for immunodetection, could account for the consistent RT-PCR identification of the cognate transcripts in isolated islets and FACS-purified islet cell preparations, which likely contain a limited number of these contaminating cell types. Thus, based on the cell-autonomous expression of lacZ, the $C x 43$ and $C x 45$ transcripts observed in previous studies $[14,15]$ can most likely be attributed to non-endocrine cells of islets. In some systems, connexin channels may serve as communication pathways interconnecting endothelial and endocrine cells [8]. While it is certainly conceivable that changes in endothelial cells could affect the function of nearby $\beta$-cells $[43,45,46]$, it remains to be established whether $\mathrm{Cx} 43$ fulfills any role in the underlying mechanism. Therefore, mice with endothelial cell-restricted deletion of $C x 43$ [22] should provide an interesting model to study the effect of endothelial cell coupling on glucose homeostasis.

In summary, using a cell-autonomous reporter gene analysis, we have shown that, within pancreatic islets, Cx36 is the prominent, if not the sole connexin isoform expressed by the insulin-producing $\beta$-cells, whereas $\mathrm{Cx} 43$ and $\mathrm{Cx} 45$ are mostly expressed by vascular islet cells.

\section{Acknowledgments}

We thank Gabriele Matern, Gerda Hertig, and P. SeveriDe Marco for excellent technical assistance and Dr. Cor de Wit (Munich) for additional TIE2-cre, Cx43 flox mice. M.T. received a stipend of the Graduiertenkolleg "Pathogenese von Krankheiten des Nervensystems". Work in the Bonn laboratory was supported by grants from the German Research Association (SFB 400, B3 and SFB 284), the European Union (QLK3-CT-2002-01777) and by Funds of the Chemical Industry to K.W. Work in the Geneva laboratory was supported by grants from the Swiss National Foundation (31-67788.02), the Juvenile Diabetes Research Foundation International (1-2001-622), the European Union (QLRT-2001-01777), the Fondation Romande pour la Recherche sur le Diabète and the National Institute of Health (DK-63443-01).

\section{References}

[1] N.M. Kumar, N.B. Gilula, The gap junction communication channel, Cell 84 (1996) 381-388.

[2] K. Willecke, J. Eiberger, J. Degen, D. Eckardt, A. Romualdi, M. Güldenagel, U. Deutsch, G. Söhl, Structural and functional diversity of connexin genes in the mouse and human genome, Biol. Chem. 383 (2002) $725-737$.

[3] R.D. Veenstra, Size and selectivity of gap junction channels formed from different connexins, J. Bioenerg. Biomembr. 28 (1996) $327-337$

[4] B.J. Nicholson, P.A. Weber, F. Cao, H. Chang, P. Lampe, G. Gold- berg, The molecular basis of selective permeability of connexins is complex and includes both size and charge, Braz. J. Med. Biol. Res. 33 (2000) 369-378.

[5] T.M. Suchyna, J.M. Nitsche, M. Chilton, A.L. Harris, R.D. Veenstra, B.J. Nicholson, Different ionic selectivities for connexins 26 and 32 produce rectifying gap junction channels, Biophys. J. 77 (1999) $2968-2987$.

[6] G.S. Goldberg, P.D. Lampe, B.J. Nicholson, Selective transfer of endogenous metabolites through gap junctions composed of different connexins, Nat. Cell Biol. 1 (1999) 457-459.

[7] W.H. Evans, P.E. Martin, Gap junctions: structure and function, Mol. Membr. Biol. 19 (2002) 121-136.

[8] J.A. Haefliger, S. Demotz, O. Braissant, E. Suter, B. Waeber, P. Nicod, P. Meda, Connexins 40 and 43 are differentially regulated within the kidneys of rats with renovascular hypertension, Kidney Int. 60 (2001) 190-201.

[9] C. Vozzi, S. Ullrich, A. Charollais, J. Philippe, L. Orci, P. Meda, Adequate connexin-mediated coupling is required for proper insulin production, J. Cell Biol. 131 (1995) 1561-1572.

[10] A. Charollais, A. Gjinovci, J. Huarte, J. Bauquis, A. Nadal, F. Martin, E. Andreu, J.V. Sanchez-Andres, A. Calabrese, D. Bosco, B. Soria, C.B. Wollheim, P.L. Herrera, P. Meda, Junctional communication of pancreatic beta cells contributes to the control of insulin secretion and glucose tolerance, J. Clin. Invest. 106 (2000) 235-243.

[11] A. Calabrese, M. Zhang, V. Serre-Beinier, D. Caton, C. Mas, L.S. Satin, P. Meda, Connexin 36 controls synchronization of $\mathrm{Ca}^{2+}$ oscillations and insulin secretion in MIN6 cells, Diabetes 52 (2003) $417-424$.

[12] C.B. Collares-Buzato, A.R. Leite, A.C. Boschero, Modulation of gap and adherens junctional proteins in cultured neonatal pancreatic islets, Pancreas 23 (2001) 177-185.

[13] P. Meda, M.S. Pepper, O. Traub, K. Willecke, D. Gros, E. Beyer, B. Nicholson, D. Paul, L. Orci, Differential expression of gap junction connexins in endocrine and exocrine glands, Endocrinology 133 (1993) 2371-2378.

[14] V. Serre-Beinier, S. Le Gurun, N. Belluardo, A. Trovato-Salinaro, A. Charollais, J.A. Haefliger, D.F. Condorelli, P. Meda, Cx36 preferentially connects beta-cells within pancreatic islets, Diabetes 49 (2000) $727-734$.

[15] A. Charollais, V. Serre, C. Mock, F. Cogne, D. Bosco, P. Meda, Loss of alpha 1 connexin does not alter the prenatal differentiation of pancreatic beta cells and leads to the identification of another islet cell connexin, Dev. Genet. 24 (1999) 13-26.

[16] V. Serre-Beinier, C. Mas, A. Calabrese, D. Caton, J. Bauquis, D. Caille, A. Charollais, V. Cirulli, P. Meda, Connexins and secretion, Biol. Cell 94 (2002) 477-492.

[17] P. Meda, M. Chanson, M. Pepper, E. Giordano, D. Bosco, O. Traub, K. Willecke, A. el Aoumari, D. Gros, E.C. Beyer, L. Orci, D.C. Spray, In vivo modulation of connexin 43 gene expression and junctional coupling of pancreatic B-cells, Exp. Cell Res. 192 (1991) 469-480.

[18] M. Zhang, R. Bertram, A. Sherman, L.S. Satin, Contribution of gap junctional currents to islet electrical activity, Diabetes 51 (Suppl. 2) (2002) A-374.

[19] M. Perez-Armendariz, C. Roy, D.C. Spray, M.V. Bennett, Biophysical properties of gap junctions between freshly dispersed pairs of mouse pancreatic beta cells, Biophys. J. 59 (1991) 76-92.

[20] P. Meda, A. Perrelet, L. Orci, Increase of gap junctions between pancreatic B-cells during stimulation of insulin secretion, J. Cell Biol. 8 (1979) 2441-2448.

[21] O. Krüger, A. Plum, J.S. Kim, E. Winterhager, S. Maxeiner, G. Hallas, S. Kirchhoff, O. Traub, W.H. Lamers, K. Willecke, Defective vascular development in connexin 45-deficient mice, Development 127 (2000) 4195-4202.

[22] M. Theis, C. de Wit, T.M. Schlaeger, D. Eckardt, O. Krüger, B. Döring, W. Risau, U. Deutsch, U. Pohl, K. Willecke, Endothelium-specific replacement of the connexin 43 coding region by a lac $\mathrm{Z}$ reporter gene, Genesis 29 (2001) 1-13. 
[23] A. Plum, G. Hallas, T. Magin, F. Dombrowski, A. Hagendorff, B. Schumacher, C. Wolpert, J. Kim, W.H. Lamers, M. Evert, P. Meda, O. Traub, K. Willecke, Unique and shared functions of different connexins in mice, Curr. Biol. 10 (2000) 1083-1091.

[24] K. Akagi, V. Sandig, M. Vooijs, M. Van der Valk, M. Giovannini, M. Strauss, A. Berns, Cre-mediated somatic site-specific recombination in mice, Nucleic Acids Res. 25 (1997) 1766-1773.

[25] P.L. Herrera, Adult insulin- and glucagon-producing cells differentiate from two independent cell lineages, Development 127 (2000) $2317-2322$

[26] A.G. Reaume, P.A. de Sousa, S. Kulkarni, B.L. Langille, D. Zhu, T.C. Davies, S.C. Juneja, G.M. Kidder, J. Rossant, Cardiac malformation in neonatal mice lacking connexin43, Science 267 (1995) 1831-1834.

[27] Y. Lallemand, V. Luria, R. Haffner-Krausz, P. Lonai, Maternally expressed PGK-Cre transgene as a tool for early and uniform activation of the Cre site-specific recombinase, Transgenic Res. 7 (1998) $105-112$.

[28] M. Güldenagel, J. Ammermüller, A. Feigenspan, B. Teubner, J. Degen, G. Söhl, K. Willecke, R. Weiler, Visual transmission deficits in mice with targeted disruption of the gap junction gene connexin 36 , J. Neurosci. 21 (2001) 6036-6044.

[29] C. Brink, P. Gruss, DNA sequence motifs conserved in endocrine promoters are essential for Pax4 expression, Dev. Dyn. 228 (2003) $617-622$.

[30] C. Brink, K. Chowdhury,P. Gruss, Pax 4 regulatory elements mediate beta cellspecific expression in the pancreas, Mech. Dev. 100(2001)37-43.

[31] C. Brink, Promoter elements in endocrine pancreas development and hormone regulation, Cell. Mol. Life Sci. 60 (2003) 1033-1048.

[32] B. Hogan, R. Beddington, F. Costantini, E. Lacy, Manipulating the Mouse Embryo, Cold Spring Harbor Laboratory Press, Plainview, NY, 1994.

[33] F.D. Houghton, E. Thönnissen, G.M. Kidder, C.C. Naus, K. Willecke, E. Winterhager, Doubly mutant mice, deficient in connexin32 and -43 , show normal prenatal development of organs where the two gap junction proteins are expressed in the same cells, Dev. Genet. 24 (1999) 5-12.

[34] B. van der Loo, M.J. Fenton, J.D. Erusalimsky, Cytochemical detection of a senescence-associated beta-galactosidase in endothelial and smooth muscle cells from human and rabbit blood vessels, Exp. Cell Res. 241 (1998) 309-315.

[35] G.M. Beattie, F. Levine, M.I. Mally, T. Otonkoski, J.S. O’Brien, D.R. Salomon, A. Hayek, Acid beta-galactosidase: a developmentally regu- lated marker of endocrine cell precursors in the human fetal pancreas, J. Clin. Endocrinol. Metab. 78 (1994) 1232-1240.

[36] M. Theis, C. Mas, B. Döring, O. Krüger, P. Herrera, P. Meda, K. Willecke, General and conditional replacement of connexin43-coding DNA by a lacZ reporter gene for cell-autonomous analysis of expression, Cell Adhes. Commun. 8 (2001) 383-386.

[37] M. Theis, R. Jauch, L. Zhuo, D. Speidel, A. Wallraff, B. Döring, C. Frisch, G. Söhl, B. Teubner, C. Euwens, J. Huston, C. Steinhaeuser, A. Messing, U. Heinemann, K. Willecke, Accelerated hippocampal spreading depression and enhanced locomotory activity in mice with astrocyte-directed inactivation of connexin43, J. Neurosci. 23 (2003) $766-776$

[38] M.R. Deans, J.R. Gibson, C. Sellitto, B.W. Connors, D.L. Paul, Synchronous activity of inhibitory networks in neocortex requires electrical synapses containing connexin36, Neuron 31 (2001) 477-485.

[39] M. Cohen-Tannoudji, S. Vandormael-Pournin, J. Drezen, P. Mercier, C. Babinet, D. Morello, lac Z sequences prevent regulated expression of housekeeping genes, Mech. Dev. 90 (2000) 29-39.

[40] E. Giordano, V. Cirulli, D. Bosco, D. Rouiller, P. Halban, P. Meda, B-cell size influences glucose-stimulated insulin secretion, Am. J. Physiol. 265 (1993) C358-C364.

[41] M. Van De Winkel, D. Pipeleers, Autofluorescence-activated cell sorting of pancreatic islet cells: purification of insulin-containing Bcells according to glucose-induced changes in cellular redox state, Biochem. Biophys. Res. Commun. 114 (1993) 835-842.

[42] K. Docherty, Growth and development of the islets of Langerhans: implications for the treatment of diabetes mellitus, Curr. Opin. Pharmacol. 1 (2001) 641-650.

[43] E. Lammert, O. Cleaver, D. Melton, Induction of pancreatic differentiation by signals from blood vessels, Science 294 (2001) 564-567.

[44] D.F. Hülser, B. Rehkopf, O. Traub, Dispersed and aggregated gap junction channels identified by immunogold labeling of freeze-fractured membranes, Exp. Cell Res. 233 (1997) 240-251.

[45] B. Duvillié, C. Currie, T. Chrones, D. Bucchini, J. Jami, L.R. Joshi, D.J. Hill, Increased islet cell proliferation, decreased apoptosis, and greater vascularization leading to $\beta$-cell hyperplasia in mutant mice lacking insulin, Endocrinology 143 (2002) $1530-1537$.

[46] P.O. Carlsson, C. Berne, L. Jansson, Angiotensin II and the endocrine pancreas: effects on islet blood flow and insulin secretion in rats, Diabetologia 41 (1998) 127-133. 